\title{
Law Enforcement against Criminal Acts in Politics in Indonesia Connected with Positive Law
}

\author{
Subarsyah ${ }^{1}$ \\ ${ }^{1}$ Universitas Pasundan, Bandung, Indonesia \\ Correspondence: Subarsyah, Universitas Pasundan, Bandung, Indonesia. E-mail: subarsyah.fh@unpas.ac.id
}

Received: February 9, 2017

Accepted: April 13, $2017 \quad$ Online Published: June 1, 2017

doi:10.5539/jpl.v10n3p51

URL: https://doi.org/10.5539/jpl.v10n3p51

\begin{abstract}
Political crimes are deemed to be problem, especially regarding their enforcement. Positive law has been set but the political crimes continue to occur. It is presumably caused by unpreparedness of the supporting factors to compensate for sophisticated and varied political crimes, criminal sanctions and a weak political will. As a result, there is a gap because of the breach of the law principles itself. Accordingly, it is necessary to study whether the positive law enforcement can reach all kinds of political crimes, how the criminal policies are formulated and the constraints and solutions to be pursued. In exposing the above issues, this research is descriptive analysis using normative juridical method. Their validity are checked through triangulation examination technique and then analyzed by qualitative analysis. The results revealed that political crimes are crimes against public interest and the occurrence process relates with the power and political activity as their means. If the power and political activity are synergized and strong, the political crimes will find their perfection. Positive law is essentially the result of a series of political processes. Consequently, any enforcement effort of positive law on political crime cannot be completed because political crime always coincides with high-tech, high management and high politic beyond the boundaries of reality (law, morality, culture and common sense). It then develops into a discourse that is planned, organized and controlled to be untouched and unreached crime. Meanwhile, positive law works in a linear-mechanistic way based on doctrine of Legal Positivism or Rechtsdogmatiek by promoting criminal policy in the form of penal policy that in reality had lost much of its authority.
\end{abstract}

Keywords: law enforcement, criminal acts in politics, positive law, Indonesia

\section{Introduction}

One of the legal problems which is always interesting to be criticized is concerned with the law enforcement of the Crime of Politics, either in its pure form as a political crime directly striking on the ideology of the state or as an ordinary crime committed by politicians or political functionaries or a crime in their political activities as an intermediary before entering the goal of a state's ideology. The reason is that the type and form of the positive criminal law in the Penal Code of Indonesia (KUHP) or specifically spread in the regulation outside the Penal Code of Indonesia (KUHP) at the stage of implementation of the enforcement often encounter obstacles which include political pressure, the social pressure, as well as a variety of reasons outside the law (politically motivated) resulting in the escape of perpetrators of political crimes from the (positive) law. Even further, the perpetrators of political crimes try to escape from the law by often manipulating the principles of the law by hiding behind the presumption of innocence, there are no laws that govern them (principle of legality), acting in their positions, carrying out orders legislation (inhibit the democratic process), cannot be applied retroactively, pushing through a constitutional test process (although the reason is not strong), examination of the public, even giving accusation of violating human rights. Thus, there is a crisis of confidence in the due process of law attacking the dignity of the court (contempt of court), discrimination legal treatment (equality before the law) etc. In short, positive law is actually tested by the domination of politics and in position to remain as a subordinate politic on the pretext that the (positive) law is the product of a series of political process establishing the fact that the law is only a tool solely for power. How great the law is toyed with a series of simulation as if a crime does not occur because it is wrapped with the duplication above duplication (simulacra) which in turn the authentic truth become invisible, untouchable and unreachable. Eventually it becomes a perfect crime.

If it is traced to touch the root of the problem in depth, all the problems assumed to be not only related to questions of legal system, but also a political problem of legal and political criminals considering the dominance of legal 
positivism in the repertoire of growth, the dynamics and application of the law is so strong, so that the values contained in other legal sources outside the law get ignored and marginalized (keep on following the written law yet neglecting the values of unwritten law). Legal positivism is a philosophical school in the positivism of the process of law which place the law in a rational building with a rational method. It is on that basis that the legal positivism in terms of seeing the reality is supposed as always in order, regular and formal (Static-mechanistic). Meanwhile what is happening here, political crimes for example, actually moves very dynamically and smoothly, even variedly (impressed wildly). Wherein the process has a strong synergy with the power supported by high-tech, high management complexity and high political growth, so that it goes beyond the rational limits (law, morality, culture and common sense) which sometimes leaves the institutionalized values as contained in the positive law.

Accordingly, it needs to be re-examined on the nature of (the basic essence) the existence of positive law, political law, politics crime, positive law enforcement in the general law enforcement, including the political will of all the organizers of the state in particular to cope with the political crimes which grows so fast and tend to be smoothly influences various fields of development.

In line with the description in the above background, this research formulates the problems as follows:

1) Has law enforcement been enforceable against all kinds of political crimes or criminal acts in politics as regulated in positive law?

2) How criminals politic is formulated to cope with political crimes through its law enforcement?

3) What obstacles are faced to enforce the law against t the political crimes or criminal acts in politics and what are the solutions to be able to contribute to the renewal concept of the Penal Code of Indonesia (KUHP) and Criminal Procedure Code of Indonesia (KUHAP)

\section{Materials and Methods}

It needs a few theories as the foundation for uncovering matters of law against political crimes or criminal acts in politics, namely: Thought (theory) about the relevance of the law with popular culture as developed by Yehezkel Dror, or the relevance of law and the public opinion of AV Dicey, to understand that the substance of the rule of law as confirmed by Satjipto Rahardjo as an attempt to realize the desires of law. Because, as stated by CF Louis L Jaffe, that the law is a living organism whose durability is heavily dependent on the renewal and improvement. This condition encourages the system theory in the law, namely to formulate the law on the basis of a set of units which are regularly interdependent as a whole.

This situation, according to Joseph A Litterer, is an exploration of the human intellect in finding the most appropriate way to learn a complex entity or system including to apply the positive law against the crime in relation to the politics of law and political criminals to reform the Penal Code (KUHP) and Criminal Procedure (KUHAP). The focus of the discussion of the observed object, i.e. political crimes or criminal acts in politics, the theory of objective, the theory of the subjective, the theory of predominance and theory of political incidence were used as already developed by Hazewingkel Suringa as its measure; whether an act is included or not to a political crime. While to look at the effectiveness of sanctions, the principles of criminal imposition was used as developed by Jeremy Bentham, Ted Hondericht and Nigel Walker.

The method of this research is a descriptive analysis using normative juridical approach. Type of data are in the form of theories or concepts of law collected through library research recorded in detail. The researcher was actively involved into the instrument. Checking the data was done through a data triangulation which means checking the data was employing the use of a variety of perspectives to interpret a set of data so as not to bias the results. Meanwhile, the data analysis used a qualitative analysis, which is a form of analysis that does not use standard calculation of statistics to find the meaning of the data and information.

\section{Results and Discussion}

\subsection{The Reality of Positive Law and Its Problematic Enforcement against Political Crime}

Model of crime prevention, is generally known to have three types, namely: First, through an implementation of the criminal law (criminal law application) second, through a precaution without a crime (prevention without punishment) and third, through a combination between the application of the crime and prevention without crime.

The first model is through the penal law (criminal Law) focusing on efforts that are repressive (enforcement, eradication and crushing). The second model is a non-penal way (without the criminal law) that focuses on preventive efforts (prevention, guidance and control). While the third model is using the penal and non-penal simultaneously by combining repressive and preventive. 
Particularly for the application of the first model, which is repressive, stated by Jeremy Bentham ${ }^{1}$ that the criminal law should not be used if: Without Basic (Groundless), Not Beneficial (Needless), Inefficient and Useless (unprofitable). Furthermore Ted Honderich stated that criminal law can be effective, if: The criminal law must earnestly prevent, not cause a situation which is more dangerous or harmful than if the criminal is not charged and no other penalties can effectively prevent a hazard or smaller loss. On the grounds that, the next Nigel Walker ${ }^{2}$ suggested the imposition of criminal principles as follows:

a. The criminal law should not be used solely for retaliation

b. The criminal law should not be used to criminalize acts that do not harm or endanger

c. The criminal law should not be used to achieve a goal that can be achieved more effectively by other lighter means

d. The criminal law should not be used if the caused harm or danger is greater than the action itself

e. Prohibitions criminal law should not be more dangerous than the nature of the act to be prevented

f. The criminal law must contain prohibitions that do not receive strong support from the public.

The relation to the implementation of the rule of law (positive criminal law), if it is observed apparently Positive Law in Indonesia still tends to be formal-legalistic ${ }^{3}$. That is, everything must be in accordance with the legislation. This is logical considering the character of the existing law also tends to be positivistic ${ }^{4}$. i.e. everything must be based on the values that have been defined. Thus, positivistic paradigm in Indonesian criminal law enforcement will dominate the culture of law enforcement officials and even to this day; the fact shows Indonesia positive Criminal Law (not including customary law) is still dominated by colonial legacy, where material, substance and the basic philosophy will remain more or less influenced by the colonial character as well. Therefore, the implementation of law enforcement happening will not ultimately lead to the achievement of the objective of the law positively in accordance with the values believed by all Indonesian people, namely to achieve justice for the realization of a just and civilized welfare state in accordance with the foundation, Pancasila. Even if at present the legislation from colonial legacy is followed by a set of new laws with various modifications (promoted as national conditions), but the previous main law itself still is fundamentally unchanged, it remains that the born law will be only a sub-system of the previous main law. It will not be completely sterile apart from its function as a tool that has a tendency as a legitimacy of power. In such circumstances, according to Nonet and Selznick, that law will remain on the repressive stage. When the dominance of positivistic law exists, then law enforcement will not be able to get out of the treatment condition which concerns more with the interest of certain groups with high position and strong economic status, which in turn will bring a discriminatory treatment. Many examples can be quoted as a valuable lesson, where law enforcement is inconsistent to be on the track of equality before the law, one of which is concerned about the law enforcement of the former president Soeharto, which until his death just became the historical record. This momentum is then used as a model by a number of individual state officials, individual holders of public office, politicians, holders of public office and a number of owners of economic power of black class, even unscrupulous law enforcement though instead opt to do so. Recently, many cases frequently reveal in relation to the implementation of the law enforcement (positive penal law). It seems true that the positive Law in Indonesia is still formal-legalistic, if it is thoughtfully watched. Everything must be in accordance with the legislation. This is so reasonable considering the character of the existing law which also tends to be positivistic; everything must be based on the values that have been defined. Thus, positivistic paradigm in Indonesian criminal law enforcement will dominate the culture of law enforcement officials and even to nowadays. Indonesia positive Criminal Law (not including customary law). In fact, it is still dominated by colonial legacy in which material, substance and basic philosophy will, more or less, still get influenced by the colonial character of power. Therefore, the implementation of law enforcement will not ultimately lead to the achievement of the objective of the law which is positive in accordance with the values believed by all the Indonesian people, namely to achieve justice for the realization of a just and civilized welfare state in accordance with its foundation, Pancasila. Even if at present

\footnotetext{
${ }^{1}$ Nigel walker, Sentencing in a rational society, Newyork,1972, page 15

${ }^{2}$ Nigel Walker, Sentencing A Rational Society, ibid

${ }^{3}$ Formal legalistic is characteristic of law from the teachings of legism. The idea is the statute is the only called law, the laws outside it are considered no law. Statute or Legislation is considered the most likely to deliver anything. It is considered the god of the law. The thinkers of it are John Austin, Hans Kelsen, Max Weber and Adolf Merkel.

${ }^{4}$ Positivistic is a kind of school of law philosophy developing in Continental Europe. Particularly in France, it evolved through two popular exponents; Henri Saint-Simon (1760-1825) and August Comte (1798-1857). Positivism became the earliest scientific paradigms appearing after empiricism. Empiricism means reality is everything that comes through the data sensation, in other words, the knowledge should be started from the empirical verification.
} 
the legislation from colonial legacy is followed by a set of new laws with various modifications (promoted as national conditions), but the previous main law itself still is fundamentally unchanged, it remains that the born law will be only a sub-system of the previous main law. It will not be completely sterile apart from its function as a tool that has a tendency as a legitimacy of power. In such circumstances, according to Nonet and Selznick, that law will remain on the repressive stage. When the dominance of positivistic law exists, then law enforcement will not be able to get out of the treatment condition which concerns more with the interest of certain groups with high position and strong economic status, which in turn will bring a discriminatory treatment. This condition is getting exacerbated when the positive law goes static, rigid, and merely based on the legal certainty (exalting the principle of legality), followed by only the imposition of single penal. Thus, it is completely clear that our positive law is left far behind by the growth of smooth, varied and highly dynamic crime going beyond the boundaries of reality (the law, morality, culture and common sense). It gets processed in such a way to be a discourse which is planned, organized and controlled perfectly. Such leap of crime is supported with high-tech, high management and high politics, until no longer possible to be overcome by purely linear-mechanistic approach as merely relying on the application of the teachings of Legal Positivism or Rechtsdogmatiek as today. Here and on this stage, it is necessary to do a rearrangement (reconstruction) through an approach of a court management totally (total quality management) in order that the law is more progressive and the enforcement is accommodating to optimize various alternative values to grow, develop, and to be adhered by the society by promoting a preventive approach rather than a repressive approach. Steps are therefore believed to be established, that in the case of law enforcement, the application of criminal sanctions is the ultimate weapon (ultimum remedium), including for tackling political crimes. If it continues that the law enforcement against political crimes solely refers to the positive law using the approach pattern which puts sanctions in the form of single penal (criminal prosecution), it is certain that the results will not be effective to be able to reach all types and forms of political crime which grows quickly and gets more varied. That is why the direction of political crime should be immediately corrected by shifting the approach of the crime imposition from prioritizing criminal sanctions (entities) to putting forward subject to a fine (this is important as criticized by E.Utrecht ${ }^{5}$, in modern criminal law for certain matters, a heavy penalty will be better and more useful than the short-term corporal punishment), or replaced with a socially sanctioned form in the form of social work or the work of the profession. Similarly, at the stage of its disclosure, considering that the political crime is a high level crime, the pattern of enforcement should also include a high-tech, high management high sensitivity of dynamics and high political insight so that the "pattern of secret game (a confidence game)" as termed by Abraham S Blumber, can be anticipated, and what Dynisios Spinellis called as "the phenomenon of twins" does not occur. It is a penalization of politics and the politizing of criminal proceedings ${ }^{6}$. Meanwhile, regarding the term of political crime in accordance with article 5 of Law No. 1 of 1979 on Extradition, it is a juridical term. So, assuming the view that the term for political crimes only a sociological term, public term or scientific term is totally; If in view of the positive law in Indonesia, totally incorrect. This is important to deliver to avoid any doubt in any further discussion.

Political crime is included as a crime against the public interest which always involves the law, power and politic in a state. When an evil crime is hiding behind the power, the line between crime and the authority becomes biased precisely because a state is a patron tool. When the state symbols are used as a tool of evil, then evil will find its most perfect form, namely a perfect crime. The occurrence of crimes by the state in the legal literature is known as symbolic violence, which is a kind of crime that is committed subtly through the specific mechanism using state symbol as a tool, as a pretext for the general welfare, for safety's sake, for the sake of certainty, for stability, etc., which in semiotics is intended as an attempt to conceal the real crime. In such circumstances, Abraham Blumber precisely stated that there had been "a game full of secrets" (a confidence game) which could not only happen in the cultural domain of justice, but also in the circles of power in a state concerning holders of public office, the political office, politicians and political community and the dynamics of political reality. In short, such a high level of crime can be committed by state officials, government officials, state defense instruments, commander of order and justice as well as ordinary people who are in the circle of power.

In connection with that, Luis Althuser distinguished the political criminals into 2 (two) groups, namely: First, the state apparatus (Repressive state apparatus) including the Government, Administration 'State, the Armed Forces, Police, Courts and Prison officers. Second, the offenders outside the state apparatus (ideological state apparatuses) including religious organizations, education, trade unions, political organizations and cultural communities, all of

\footnotetext{
${ }^{5}$ E. Utrecht, Rangkaian sari kuliah hukum Pidana II, Pustaka Tinta, Surabaya,1986, pp. 317

${ }^{6}$ In Barda Nawawi Arief, Masalah hukum dan Kebijakan Hukum Pidana dalam penanggulangan Kejahatan, Pranada Media, Jakarta, 2007, pp. 177
} 
which work using non-violent mechanism of ideology. Meanwhile, it is known from the literature that what so-called political crimes in the view of the scientists and public view is still different. Some call it as a crime against the State and the security of the State; Crime against the political system; Crime against the power system; Crime against the basic values (human rights), politically motivated crime; Crime in achieving, sustaining and conquering power; Crime against political institutions; Crime by state authorities or politicians and crime in the office, which is in the positive law of Indonesia set forth in the provisions of articles 104-129 of the Penal Code (KUHP) including acts of assault (Articles 104-107 Penal Code), rebellion (Article 108), agreement with foreign countries (article 110-111 Penal Code), Crime against National Defense building (articles 117-120), Diplomatic Crime (article 121 Penal Code), spies (articles 122-125 Penal Code), desertion (article 126 Penal Code), guile on military goods (article 127 of the Criminal Code) or specifically previously in PNPS Law No. 11/1963 on subversion and later in the constitution No. 27 of 1999 on Crime against State Security and No. 10 of 2008 on General Election. The enforcement of the positive law above is not yet effective to overcome many kinds of political crimes nowadays. Because it works perfectly, it is still hidden behind the economic power such as bribery, kickbacks, tax evasion, credit fraud or the most frequent crimes are embezzlement and misappropriation of public funds ${ }^{7}$. Those are crimes which are unreachable by law (offenses beyond the mach of the law) because such crimes are invisible, whereas they are more sinister than ordinary crimes (blue collar crime) which have strong political background and dominantly integrated with political process. It directly causes the collapse of economic state, striking public interest.

Loeby Loqman interpreted the political crime as a classic example, which is a crime against state security ${ }^{8}$. While Stephen Schaper stated that political crime is an extraordinary crime ${ }^{9}$. Including the crimes described earlier.

From the different understandings proposed by the experts above (including the Positive Law) it can be identified that to core of political crime is the crime which is not separated from the power of the state, including the crime coming from the government system, political system, political institutions or political dynamics leading ultimately to the effort to achieve, sustain overthrow the power. The power here is in a broad sense including the power in the field of economy, social, politic, defense and security and other powers directly affecting the public interest. The crimes related to the power and authority holders (formal) have several terms, such as crime of the powerful, abuse of public and political power, crime by government, and crime of politicians in office. Such crimes, by Edwin H. Sutherland, are called white collar crimes which is one form of crime committed by people who have high position and honorable work ${ }^{10}$. Whereas Dyonisios Spinellis called it as Top Hat Crime including; (a) violation of basic rules about struggle for power and political game; (b) violation of human rights to achieve and maintain physical power; (c) corruption and economic scandals such as embezzlement of public wealth, bribery, nepotism in public service, misuse of information and falsification of public documents; (d) all other crimes committed by politicians or public officials in carrying out their duties ${ }^{11}$.

If viewed from the anatomy, political crime which is called Top Hat Crime by Dyonisios Spinellis has the following characteristics: (1) contains elements of abuse of public office; (2) contains elements of breach of trust or abuse of trust; (3) has relationship with serious public interest of law; (4) usually committed with the support of civil servant or political party, while the politician acts as proponent; (5) difficult to be detected or proven, and (6) results in the twin phenomenon namely penalization of politics and the politicization of the criminal proceeding.

According to Bagir Manan, law enforcement is one of the aspects in implementing the law which functions to maintain the law in order to be obeyed and run properly. Law enforcement is a reaction from an event which violates the law ${ }^{12}$. In fact, the positive law in Indonesia as described earlier, often fails to overcome political crime. Let alone to predict for prevention purpose of the possible political crime which might be more sophisticated in the future.

In short, the failure of law enforcement to the emergence of diverse political crimes after understanding the characteristics of the perpetrator, elements and anatomy, is apparently triggered by; the understanding of the positive law which is "too textual", the circumstances of law enforcement elements which are not actual and

\footnotetext{
${ }^{7}$ Robert Thobaben, Issues In America Political Life, Prentice Hall,1995, pp. 70, see also Artidjo Alkotsar, Korupsi Politik di Negara Modern, pp. 34-35,

${ }^{8}$ Barda Nawawi Arief, Kebijakan penanggulangan kejahatan politik dengan hukum pidana, ibid

${ }^{9}$ Stephen Schafer, The Political Criminal, The free Press, New York, 1973, pp. 19-22

${ }^{10}$ J.E. Sahetapy, kejahatan korporasi, PT. Refika Aditama, Bandung, 2002, pp. 5

${ }^{11}$ Dyonisios Spinellis, Crime of politicians in office, in Helmut EPP (ed), crimes by government, International congress of penal law : Rio de Jeneiro,1994, pp. 19-23

${ }^{12}$ Bagir Manan, Penerapan Penegakan Hukum Lingkungan di Indonesia, paper in a seminar at Faculty of Law Unpad, Bandung, 2002, pp. 4
} 
accommodating, and strong intervention from the external non-law side. This is supported by high-tech, high management, high politics controlled perfectly as an integrated system that is far from the objective condition of (positive) law enforcement done so far.

\subsection{Law Enforcement in the Direction of the Political Law and Criminal Policy}

Law enforcement is within the sociological area, meaning that law enforcement will always be associated with the community so the law protects public interest. Soerjono Soekanto explained that the essence of law enforcement lies in activities harmonizing the relationship span in the firm principles to create, maintain and sustain peace. Law enforcement is an effort to realize the law. As stated by HLA Hart, law essentially contains ideas or concepts. In this circumstance, by Satjipto Rahardjo, law is classified as an abstract idea. According to Gustav Radbruch, legal certainty (Rechtssicherheit), utility (Zweckmassigheit) and justice (Gerechtigheit) are included in this abstract idea.

Based on the description above, the core of law enforcement is to realize the law as an abstract idea to become a reality, either by applying the law in the concrete event or formulating concrete event into legal event, maintaining the law to be obeyed. And this is a reaction to any unlawful event in order to achieve harmonious values, process and purpose of law. It is understandable why Soerjono Soekanto stated that law enforcement is not merely the enforcement of the Act, but also should pay attention to:

1) Giving example of compliance by law enforcement officials

2) Direct attitude (Zakelijke) of the law enforcement officials

3) Adjustment of regulations with cutting-edge technology

4) Counseling about the applicable regulations to public

5) Giving enough time for people to understand new regulations made.

Law enforcement is critical because as confirmed by CF Louis ${ }^{13}$, the law is basically living organisms whose durability depends heavily on the renewal and improvement. Law needs to be modernized and breakthrough in line with the growth of community and social need. This is for the sake of enforcement itself.

Because the durability of the law depends on the renewal and improvement, law will be directly related to politic of law. Politic of law, according to Sudarto ${ }^{14}$, is the policy of the state through the authorized agencies to assign the desired action and expected to be used for expressing what is aspired. According to Satjipto Rahardjo ${ }^{15}$, politic of law is selecting activities and the way that would be used to achieve a social objective and certain law in the population, which is written, not-written, or codified. Soediman Kartohadiprodjo referred to it as a basic policy to determine the direction, form and content of the laws established ${ }^{16}$. Explicitly, Padmo Wahyono ${ }^{17}$ viewed politic of law as the statement of the will of the State ruler concerning the applicable law in its territory and the legal development direction which is built. The view is in line with the Abdul Hakim Garuda Nusantara ${ }^{18}$ stating that the politic of law is a legal policy to be applied or implemented nationally by a particular government.

Attaching the politic of law to the law which is living organism depends on the improvement and renewal. Thus, the subject will then intersect with the political will and top management commitment political process as a series of political process of (positive) law establishment. And if the political will and commitment is separated from the nature of law purpose (realizing justice, certainty, and order), the (positive) law formed will eventually lose its substance and integrity. It is because the (positive) law mere becomes instrument of the power. Furthermore, law enforcement will encounter difficulty because the (positive) law uphold has failed to articulate the values growing and thriving in the community. In fact, those growing values should actually be the basis of renewal or improvement of law to solicit public support when the law is applied. It is the logic consequence of law enforcement within the sociological area.

The same condition will occur in the enforcement of criminal law because criminal policy is part of politic of law in a broad sense. Criminal policy is also a part of social policy in the form of society and state efforts to improve the

\footnotetext{
${ }^{13}$ C.F. Louis

${ }^{14}$ Sudarto, Hukum pidana dan perkembangan masyarakat : Kajian terhadap pembaharuan hukum pidana, Sinar Baru, Bandung, 1983, pp. 20

${ }^{15}$ Satjipto Rahardjo, Ilmu Hukum, opcit , pp. 309

${ }^{16}$ Soediman Karto Hadiprodjo, Pengantar Tata Hukum Indonesia, PT. Ghalia Indonesia, Jakarta, 1974, pp.50

${ }^{17}$ Padmo wahyono, Indonesia Berdasarkan atas Hukum, Ghalia Indonesia, Jakarta, 1986, pp.160

${ }^{18}$ Abdul Hakim Garuda Nusantara, Politik Hukum Nasional, a paper presented at law workshop, YLBHI-LBH Surabaya, 1985
} 
welfare of citizens. Criminal policy, according to Sudarto ${ }^{19}$ could be narrow, broad and very broad in its meaning. Narrow means the overall principles and methods which become the basis of the reaction to the violation of criminal law. Criminal policy in broad meaning is all the functions of law enforcement officials, including the courts and the police officers. Criminal policy in a very broad meaning covers all policies pursued by the legislation and official bodies aimed at enforcing the central norms of society. Briefly, according to Sudarto, criminal policy is about how to promote, create, and formulate a good criminal law. Thus, implementing criminal law means to provide options to achieve the most qualified law result in terms of fairness and efficiency. March Ancel $^{20}$ affirmed that the criminal policy is a science and art allowing the regulation of positive law to be formulated better to provide guidance only to lawmakers but also to the Court applying the law, the organizers and executors of court decisions.

If the positive law as a form of politic of law accomplished through a political process occurs and goes solely for the sake of power, the criminal policy which is also part of the politic of law will in turn form and lead to the efforts to retain power. If the law and power going in such a way without clear boundaries, the potential of the law to be used as a tool of crime is likely to occur. Furthermore, the crime will arise, hide or make power as its protector. If the crime is successfully fused and synergized with this power, the law will not have the driving force because the (positive) law is essentially a product of the power itself. Therefore, the law enforcement in such situation become ineffective in reaching the crime (including any political crime) because the crime is born into a completely perfect crime, and every crime is transformed into a crime that is untouched or uncovered by law (white collar crime, top hat crime, organized crime or corporation crime). In short, the crime managed to find a place that is perfect, hiding behind the power to make law as a means of crime.

From the description above, it can be known why many political crimes often escape from the law. It is because the political laws are formal-legalistic which directly influences the politic of crime into formal-legalistic. No wonder why the law enforcement held becomes very normative-positivistic. It is understandable that one of the core weaknesses of the positive law is always left behind by the community dynamics that originally should be acknowledged and escorted. Political crime develops so fast and varied, in line with the growth of (political) power. It is even able to go beyond the boundaries of reality (the law, morality, culture and common sense). Political crime grows in such a way into the discourse that is planned, organized and controlled perfectly. So, the pattern analyzed with a linear-mechanistic to merely prioritize the approach through the teachings of legal-positivism or rechtsdogmatiek placing of sentences as the sole means of sanctions, certainly not will effectively reach the crime. This is why there is a need to shift the political direction of law and criminal policy to be more empirical (sociological) allowing the imposition of sanctions as an alternative social safety net among other penal sanctions that had already existed and been used. It is fair if the social sanction is empowered in advance for prevention and if it is deemed advantageous for achieving the purpose of law, the penal sanctions (repressive) is applied in accordance with its nature i.e. ultimum remedium. The law policy and criminal policy are essentially part of social policy, which are efforts to reach out and realize social welfare dynamically and harmoniously.

\subsection{Obstacles, Solutions and Perspectives of Renewal of Penal Codes of Indonesia (KUHP) and Criminal Procedure Code of Indonesia (KUHAP) Related to the Political Crimes}

Based on the previous description explaining that the major obstacles of the law enforcement against political crimes lies in understanding of law which is too textual, the condition of law enforcement elements that are not real and accommodating, and the strong influence of non-legal interests that are external. Those three constraints are essentially derived from the politic of law which is still formal-legalistic and criminal policy which is Normative-positivistic, resulting in the law enforcement which prioritizes the penal sanction. This is proven by the provisions of the articles in the positive law; there is no provision which opens opportunities for social sanctions against the perpetrators of political crimes. In other words, the perpetrators of any type and form of political crime will be subject to penal (criminal) policy. This in average is in the form of criminal sanction. In fact, as affirmed by E.Utrecht, a large financial penalty will be much stronger than short-term imprisonment or confinement. It is supported by John Andenaes stating that the function of criminal law should be seen from the overall cultural context because there is influence between the law with other factors shaping attitudes and actions ${ }^{21}$. More concretely, Middendorf confirmed that other means of social control such as the power of the elderly, customs and

\footnotetext{
${ }^{19}$ Sudarto, Kapita Selekta Hukum Pidana, Alumni, Bandung, 1981, pp.113-114

${ }^{20}$ March Ancel, Social defense: A Modern approach to criminal problems, Routledge \& Keagan Paul, London, 1965, pp. 4-5.

${ }^{21}$ Johanes Andenaes, Does Punishment Deter Crime? Philosophical Perspective on Punishment, Gertrude Edzorski (ed) State University New York Press,1972, pp. 345 in Barda Nawawi, Bunga Rampai Kebijakan Hukum Pidana, PT.Citra Aditya, 1996, pp. 249
} 
religion may be able to prevent evil deeds as strong as the fear of the criminal code ${ }^{22}$. In fact, the perpetrator of political crime had never been fined in financial penalty. Even if any, the fines is usually imposed as an additional sanction (not the principal sanction or alternative sanction to imprisonment). It can be understood because, as stated by Manuel Lopez-Rey, throughout the practice, the imposition of financial penalty could be a major source of injustice ${ }^{23}$. The imprisonment can be interpreted as a character assassination and can kill political career of the perpetrator. Thus, the positive law is essentially a series of political process as part of the product of politicians. The positive law is also often used as a tool for counterattack, for example, filling for a judicial review (such as the Constitutional Court decision No. 14/PUU-IV/2008 on testing the Penal Code concerning action attacking the good reputation, Constitutional Court decision No. 16/ PUU-IV/2008 on filing judicial review on the verdict which has permanent legal force, Constitutional Court decision No. 21/PUU-IV/2008 on implementation of Death penalty, Constitutional Court decision No. 20/PUU-IV/2008 on judicial review of law No. 31 of 1999 on the crime of corruption) or expanded with a public examination on the alibi of inhibiting the democratic process, raping the Fundamental Rights (HAM), manipulating the principles of law as deliberately ridiculing the function of the presumption of innocence, absence of law governing the case (note the case of someone arguing that a policy cannot be convicted or reported, in fact he reports back because the case attacks his good reputation), pressure by mass, forgiven, outside the jurisdiction (connectivity), spreading economic power and a wide range of acts in the dimension of political pressure. In this condition, the legal process really came and is stuck in the realm of "A confidence game" (game full of secrets) as alleged by Abraham S Blumber, or even The Politicizing of Criminal Proceedings (politicization of the criminal justice process) has been happened as feared by Dyonisios Spinellis because the perpetrators consider that political penalization had happened. More bluntly, A Confidence game actually strikes down the principles of the law itself, for example by way of Contempt of Court (attacking the dignity of Justice), resulting in the law no longer to uphold the principle of Equality before the Law or the Due Process of Law. Therefore, it results in the negative effect i.e. discrimination due to the use of symbols of law and the institution as a crime media which becomes camouflages the real crime (camouflage sign). Thus, the political crime appears to be a kind of crime which is as difficult as other sophisticated crimes and categorized as a white collar crime, organized crime, or Top Hat Crime. All of these crimes are unreachable or untouched by positive criminal law. Therefore, to reveal the political crime as the perfect crime, the law enforcement on this crime is not enough with just patching through the enactment of legislation outside the Criminal Code. Nonetheless, a new solution is needed to touch the fundamental changes of its legal system, for example by shifting the paradigm from formal-legalistic to sociological-empirical so the law enforcement which is in Normative-positivistic orientation can be more Empirical-critical and adaptive to the values outside the legislation (adopting the values contained in other legal sources such as Customary law and Religious law) independent from imported products through the ratification of law. In connection with that, we need a way to prepare and establish new formulation or reformulation of various political crimes in any aspect, as already started in the draft of Penal Code, either for evaluation or anticipation. Draft of Penal Code introduced in 1977 by Tim Basaroedin (BAS) and Mardjono Reksodipoero has successfully providing some new offenses such as the spread of communism ideology, against the ideology of Pancasila, contempt of court, criminal act against religion and religious life, terrorism, genocide, criminal act of soil pollution, air and water surface, criminal acts of decency recording, phone tapping, cybercrime and even the practice of witchcraft. Asides, the classification of the crime, originally based on "qualification of offense" (Crime and Abuse), is shifted to the concept based on the weight of the offense (very light, heavy and very severe offense). This initiated the birth of criminal "Supervision" i.e. one type of criminal that does not deprive the independence of the offender by way of imprisonment, but its development is done through supervision (even if intended for criminal under 7 years) or "combination of prison and supervision". Regardless of the pros and cons, the idea is really meaningful and full of hope for so that the establishment and enforcement in Indonesia are completely free from stigma of colonialist-feudalism, changed into Nationalist-Pancasila or Unity in Diversity legal system as offered by author here. The implementation of criminal "Supervision or combined prison and supervision" according to qualification of offense is deemed to be appropriate to overcome political crimes in the future. This research encourages the realization of that idea i.e. for updating the Criminal Code, which until now has not been materialized. It is not only in the material Criminal Code (KUHP), but also in formal Criminal Code (KUHAP) which is more than a quarter century unable to reveal political crime which is smooth, fluid, varied and able to transcend the rational limit (law, morality, culture and common sense) driven by high-tech, high management and high politic so that it becomes a perfect crime. Or, as has been stated earlier that political crime belongs to the public crime and often hides behind the power or position that is packaged in semiotic through

\footnotetext{
${ }^{22}$ H.D. Hart, Ed. Punishment: For and Against, Hart Publishing.Co.Inc. New York City, 1971, pp.15

${ }^{23}$ United Nations Reports. Fifth United Nations Congress on the Prevention of Crime and The Treatment of Offenders, 1970, pp. 40
} 
"secret game". So, disclosing such crime based merely on the Criminal Code is completely ineffective. The evidences of this are; the absence of rule in Criminal Code regarding new media called Magnetic (Micro Chip), Electrical, Virtual communication, crime based on computerized system and website. These are often used as instrument of crime in the conventional as well as in political crime. The use of satellite to uncover evidence of a crime or the use of intelligence data as initial evidence, examination via teleconference or video conference are not covered in Criminal Code. In short, the high-tech, high management and high political need to get serious attention not only for renewal of material criminal law but also formal criminal law as a single integrated entity in order that the law enforcement of criminal law can reach all crimes (particularly political crime) in line with the highest legal purpose, namely justice and prosperity.

\section{Conclusion}

The implementation of the law enforcement (positive criminal law) against the political crime is formal-legalistic which means that everything must always be in accordance with the legislation in line with the character of law which is indeed static. On that basis, positivistic paradigm in turn will dominate the culture of law enforcers. When the law is dominated by positivistic, the law enforcement will not be able to go out from the condition prioritizing the groups with high position (power holders) and strong economic status because essentially the positive law is a series of political process. Further result, the enforcement of the positive law in the reality is not yet effective to overcome many kinds of political crimes nowadays. Because it works perfectly, it is still hidden behind the economic power such as bribery, kickbacks, tax evasion, credit fraud or the most frequent crimes are embezzlement and misappropriation of public funds. Those are crimes which are unreachable by law (offenses beyond the Mach of the law) because such crimes are invisible, whereas they are more sinister than ordinary crimes (blue collar crime) which have strong political background and dominantly integrated with political process. It directly causes the collapse of economic state, striking public interest. It is the failure of efforts to realize the welfare and left away from the realization of justice.

Law is basically living organism, its durability heavily depends on the renewal and improvement. That is why, law needs actualization, modernization and breakthrough in line with the growth of its social need, including for the sake of its enforcement. Therefore, directly related to politic of law, in this objective current condition, political crimes in fact are often unreachable by the law because the direction of the politic of law is formal-legalistic, which will directly affect the criminal politic becomes formal-legalistic too. Not strange if the law enforcement being implemented is very normative-positivistic, in fact as it is understandable that one of the weaknesses of the positive law is that it is always left behind the community dynamics whose harmonization should be acknowledged and escorted. Meanwhile, Political crimes is growing so fast, smoothly and variedly in line with the growth of power (political) going beyond the boundaries of reality (the law, morality, culture and common sense). Political crime is growing in such a way becoming a discourse that is planned, organized and controlled perfectly, so the pattern is analyzed with linear-mechanistic merely to give priority to the approach through the teachings of legal-positivism or rechtsdogmatiek placing the sentences as the sole means of its sanction will certainly not be effective. This is why it is necessary to have a shift of the direction of politic of law and political policy towards a more empirical (sociological) direction which allows the imposition of social sanctions as an alternative safety net among penal sanctions. It seems fair if the social sanctions are empowered as a preventive action, then if those are deemed advantageous for law enforcement, penal sanctions will be applied (repressive) in accordance with its nature as ultimum remedium. The reason is that the law of politic and criminal policy are essentially a social policy which is an effort to reach and realize social welfare dynamically and harmoniously.

The main obstacle in law enforcement against political crimes lies in understanding the law that are too textual, the condition of law enforcement elements that are not real and accommodating, and the strong influence of non-legal interests that are external. Those three points of constraints are essentially derived from the politic of law which is still formal-legalistic and criminal policy which is Normative-positivistic, resulting in the law enforcement which prioritizes the penal sanction, the pattern is analyzed with linear-mechanistic merely to give priority to the approach through the teachings of legal-positivism or rechtsdogmatiek placing the sentences as the sole means of its sanction will certainly not be effective. In response to the shortcomings, the experts then initiated the draft of Penal Code (KUHP) offering several new offenses, shifting from nature of the offense (crime and abuse) to weight of the offense, even initiated also new types of sanctions in the form of "monitoring sanction" and "combined sanctions". Not only that, the Criminal Procedure Code (KUHAP) is also encouraged to accommodate new media called Magnetic (Micro Chip), Electrical, Virtual communication, based on computerized system, website, etc., often used as an instrument of crime in political crimes. The law enforcement against the political crimes will not be enough by just conducting the implementation of a set of legislation outside the Penal Code (KUHP). It is necessary to find new solutions to touch the changes of its legal system fundamentally, for example, by shifting the 
paradigm from formal-legalistic to sociological-empirical, so that law enforcement which is normative-positivistic-oriented can be more sociological-critical and adaptive towards the values outside the constitution (adopting the values contained in other legal sources such as customary law and Religious law).

\section{Suggestions}

To make the law enforcement against political crimes effective, relying on the steps of measures of the Penal Code and Criminal Procedure Code by defining a set of special rules is not enough. What is really needed is a change of the legal system fundamentally beginning with the shifting of law of political and criminal policy and a law enforcement approach which is formal-legalistic or normative-positivistic and more empirical-sociological.

The shifting of politic of law and criminal policy in establishing a legal system should be preceded by growing commitments which include the acceleration of the realization of the new Penal Code (KUHP) and Criminal Procedure Code (KUHAP) which have had a very long process so that are often left away by the needs of the values which are dynamic-progressive

In order to put the prevention of political crimes into effect, it is preferable to begin the enforcement against the crimes usually committed by politicians or political officers either inside or outside their activities. It is important considering that the formulations, the elements and the requirements are very clear, and then it should be improved for more complicated crimes and those which are strongly correlated to maintain, gain or overthrow power (leading directly to the state's ideology)

\section{References}

Abdul Hakim Garuda Nusantara. Politik Hukum Nasional.

Achmad, R., \& Soemadipradja, S. (1990). Hukum Pidana Dalam Yurisprudensi. Armico, Bandung.

Adji, I. S. (2005). Si Corby: Keadilan Semu. Kompas.

Adji, O. S. (1984). Hukum: Hakim Pidana. Erlangga, Jakarta.

Adji, O. S. (1990). Delik Pers di Indonesia. Erlangga, Jakarta.

Adji, O. S., \& Adji, I. S. (2000). Contempt of Court : Perspektif Hukum Pidana. KDTN, Jakarta.

Alder, F. (1994). Criminal Justice. Mac Graw Hill, Inc, N.Y.

Ali, A. (1996). Menguak Tabir Hukum. Chandra Pratama, Jakarta.

Ali, A. (1998). Kajian Empiris Terhadap Hukum. Yasrip Watampone, Jakarta.

Ali, A. (2002). Keterpurukan Hukum di Indonesia: Penyebab dan Solusinya. Ghalia Indonesia, Jakarta.

Ali, A. (2004). Sosiologi Hukum: Kajian Empiris terhadap Pengadilan. IBLAM, Jakarta.

Alkotsar, A. (1997). Identitas Hukum Nasional. FH-UII, Jogjakarta.

Alkotsar, A. (2008). Korupsi Politik: Di Negara Moderen. FH-UII Press, Jogyakarta.

Amin, H. B. A. (2006). Penguasa, Makelar dan Dirham. Tinta, Jogjakarta.

Amirudin, \& Asikin, Z. (2004). Pengantar Metode Penelitian Hukum. PT>Raja Grafindo Persada, Jakarta.

Amrulah, A. (2006). Kejahatan Korporasi. Bayu Media, Malang.

Ancel, M. (1995). Social Defence a Modern Aproach to Criminal Problem. London Routrige and Keagan Paul.

Andrea, F. (1983). Kamus Hukum. Bina Cipta, Bandung.

Anwar, Y., \& Adang. (2003). Hyper Semiotika : Tafsir aculture Studies atas Matinya Makna. Jalasutra, Jogjakarta.

Anwar, Y., \& Adang. (2008). Pembaruan Hukum Pidana: Reformasi Hukum Pidana. PT. Grasindo, Jakarta.

Arief, B. N. (1998). Beberapa Kebijakan dan Pengembangan Hukum Pidana. Citra Aditya Bakti, Bandung.

Arief, B. N. (1999). Kebijakan Penanggulangan Kejahatan Politik Dengan Hukum Pidana. makalah pada seminar Nasional, FH.UNDIP, Semarang, 2 Oktober.

Arief, B. N. (2002). Bunga Rampai Kebijakan Hukum Pidana. Citra Aditya Bakti, Bandung.

Arief, B. N. (2006). Tindak Pidana Mayantara. PT.Raja Grafindo, Jakarta.

Arief, B. N. (2007). Masalah Hukum Dan Kebijakan Hukum Pidana dalam Penanggulangan Kejahatan. Pranada Media, Jakarta. 
Asshidiqie, J. (2004). Format Kelembagaan Negara dan Pergeseran Kekuasaan Dalam UUD 1945. FH UII Press, Jogjakarta.

Asshidiqie, J. (2005). Hukum Tata Negara dan Pilar-Pilar Demokrasi, Serpihan Pemikiran Hukum. Media dan HAM, Konstitusi Press.

Atmasasmita, R. (1983). Bunga Rampai Hukum Acara Pidana. Binacipta, Bandung.

Atmasasmita, R. (1997). Hak asasi Manusia Dan Penegakan Hukum. Binacipta, Jakarta.

Atmasasmita, R. (1998). Sistem Peradilan Pidana : Criminal Justice System : Perspectif Eksistensialisme dan Abolisionisme. Putra A Bardin, Jakarta.

Atmasasmita, R. (2005). Teori dan Kapita Selekta Kriminologi. Refika Aditama,Bandung.

Atmasasmita, R. (2006). Reformasi Hukum, HAM dan Penegakan Hukum. Mandar Maju, Bandung.

Azhari, M. T. (1992). Negara Hukum Suatu Studi tentang Prinsip-prinsipnya dilihat dari Segi Hukum Islam, Implementasinya pada Periode Negara Madinah dan Masa Kini. Bulan Bintang, Jakarta.

Azizy, Q. (2003). Menggagas Hukum Progresif Indonesia. Pustaka Pelajar, Jogjakarta.

Barents, J. (1965). Ilmu Politika: Suatu Perkenalan Lapangan. PT. Pembangunan, Jakarta.

Bassar, M. S. (1984). Tindak-tindak Pidana Tertentu di Dalam KUHP. Remadja Karya, Bandung.

Bauddrillard, J. (2000). Birahi. Bentang: Jogjakarta.

Bawengan. (1983). Hukum Pidana Dalam Teori dan Praktek. PT. Pradya Paramita, Jakarta.

Berger, P. L. (1985). Humanisme Sosiologis, diterjemahkan Daniel dhakidae : Invitation To Sociology, A Humanistic Persfective. Inti Aksara, Jakarta.

Berger, P. L. (1990). Revolusi Kapitalis. LP3ES, Jakarta.

Berger, P. L. (1990). Tafsir Sosial Atas Kenyataan : Sebuah Risalah tentang Sosiologi Pengetahuan. LP3ES, Jakarta.

Boas, G., \& Schabas, W. A. (Eds.). (2003). International Criminal Law Development In The Case Law of the ICTY. Martinus Nijhoff Publisher, Leiden/Boston.

Bonger, W. A. (n.d.). Pengantar Tentang Kriminologi, terjemahan R.A. Koesnoen, Pustaka sarjana, Jakarta.

Brener, M. H. (1986). Pengaruh Ekonomi Terhadap Perilaku Jahat dan Penyelenggaraan Peradilan Pidana. CV.Rajawali, Jakarta.

Brittan, A. (1987). Dimensi Simbolis Dari Hukum dan Kontrol Sosial, dalam Adam Podgorecki dan Cristophher J Whellan Sosiological Aproaches To Law (Pendekatan Sosiologis Terhadap Hukum) yang diterjemahkan oleh Rnc Widyaningsih \& G Kartasapoetra, PT. Bina Aksara, Jakarta.

Brugink, J. J. (1999). Refleksi Tentang Hukum, Alih Bahasa Arief Sidharta, PT. Citra Aditya Bakti, Bandung.

Budiardjo, M. (2006). Dasar-Dasar Ilmu Politik. Gramedia Pustaka Utama, Jakarta.

Busroh, A. D. (1990). Ilmu Negara. Bumi Aksara, Bandung.

Chambliss, W. J., \& Seidmman, R. B. (1971). Law: Order and Power. Reading Mass, Addision-Westley.

Deutsch, K. W. (1970). Politics and Government: How People Decide Their Fate. Boston, Houghton Mifflin.

Dhakidae, D. (2004). Peta Politik PEMILU. PT. Gramedia, Jakarta.

Dias, R. W. M. (1976). Jurisprudence. London : Butterworhs.

Dirdjosisworo, S. (1996). Anatomi Kejahatan di Indonesia. Granesia, Bandung.

Dirdjosisworo, S. (2002). Respon Terhadap Kejahatan. STHB Press, Bandung.

Drury, S. B. (1986). Hukum Dan Politik. Tarsito, Bandung.

Dworkin, R. (1973). Legal Reseach. Daedalus.

Edy Setiadi, H. Z. (Ed.). (2004). Bunga Rampai Hukum Pidana. UNISBA, Bandung.

Estiningsih, M. (2005). Fungsi Pengawasan DPRD. UNIKA, Jogjakarta.

Fajar, M. (2004). Tipe Negara Hukum. Bayu Media, Jakarta.

Flew, A. (1979). A Dictionary of Philosophy. Pan Books and The Mac Millan, Press, London. 
Forum Keadilan : No 36 tahun 2008-11-25.

Friedman, L. M. (1975). The Legal System: A Social Science Persfective. New York: Russel Sage Foundation.

Friedman, L. M. (2001). American Law An Introduction: Hukum Amerika Sebuah Pengantar. PT. TTatanusa, Jakarta.

Friedrich, C. J. (1967). Constitutional Government and Democracy: Theory and Practice in Europa and America. Blais dell Publishing Company.

Friedrich, C. J. (2004). Filsafat Hukum: Perspektif Historis. Nusamedia, Bandung.

Fuady, M. (2003). Aliran Hukum Kritis : Paradigma Ketidak Berdayaan Hukum. Citra Aditya Bakti, Bandung.

Galanter, M. (1998). Hukum Hindu dan Perkembangan Sistem Hukum India Moderen, Dalam A.A.G. Peters \& Koesriani Siswosoebroto (ed) Hukum dan Perkembangan SosialBuku Teks Sosiologi Hukum. Buku II, Pustaka Sinar Harapan, Jakarta.

Geerrtz, C. (1998). After Fact : Two Countries, Four Decades, One Antropologist. Alih Bahasa, landing Simatupang, LKIS, Jogjakarta.

Gilchrist, R. N. (1957). Principle of Political Science. Orient Longmans, Madras.

Gilissen, J., \& Gorle, F. (2005). Sejarah Hukum: Suatu Pengantar. Refika Aditama, Bandung.

Golding, M. P. (1975). Philosophy of Law. Prentice-Hall, Inc.New Jersey.

Gottschalk, P. (2007). Knowledge Management System In Law Enforcement : Technologies and Techniques. Idea Group Publishing, London. https://doi.org/10.4018/978-1-59904-307-4

Green, D. G., Grove, E., \& Martin, N. A. (2005). Crime and Civil Society. The Institute for The Studi of Civil Society, London.

Gunawan, B. (2008). Koloni Keadilan. Forum Keadilan No 301.

Hamidi, J. (2005). Hermeneutika Hukum: Teori Penemuan Hukum Baru Dengan Interpretasi Teks. UII Press, Jogjakarta.

Hamzah, A. (2001). Hukum Acara Pidana Indonesia. Sinar Grafika, Jakarta.

Hardjon, P. M. (1987). Perlindungan Hukum Bagi Rakyat di Indonesia. PT. Bina Ilmu, Surabaya.

Haris, J. W. (1987). Suatu Teori Strukturalis tentang Hukum: Suatu Tinjauan Agnostik. In D. A. Podgorecki, \& C. J. Whelan (Eds.), Sociological Aproaches To Law. yang diterjemahkan oleh Rnc. Widyaningsih dan G Kartasapoetra, PT. Bina Aksara, Jakarta.

Hart, H. L. A. (1981). The Concept of Law. Oxford at the Clarendon Press: London.

Hartono, S. (1976). Apakah the Rule Of Law itu. Alumni, Bandung.

Hartono, S. (1984). Kembali Ke metode Penelitian Hukum. FH-Unpad, Bandung.

Hartono, S. (1991). Politik Hukum Menuju Sistem Hukum Nasional. Alumni, Bandung.

Heriyanto, H. (2003). Paradigma Holistik: Dialog Filsafat, Sains dan Kehidupan Menurut Shadra dan Whitenhead. Teraju, Bandung.

Huda, N., \& Hukum, N. (2005). Demokrasi dan Judicial Review. UII Press, Jogjakarta.

Husak, D. (2008). Over Criminalization : The Limits of The Criminal Law. Oxpord University Press,Inc, Madison Avenue, New York.

Ibrahim, A. (2004). Pokok-Pokok Kebijakan Publik. Mandar Maju, Bandung.

Ibrahim, A. (2007). Merekonstruksi Keilmuan Ilmu Hukum dan Hukum Milenium Ketiga. In-TRANS-STIH Jend Sudirman Lumajang, Malang.

Indrati, E. (2000). Quo Vadis Pendidikan Hukum : Suatu Renungan bagi Paradigma Baru Dalam Wajah Hukum di Era Reformasi: (Kumpulan Karya Ilmiah menyambut 70 tahun Prof.DR. Satjipto Rahardjo), Citra Aditya Bakti, Bandung.

Isjwara, F. (1980). Pengantar Ilmu Politik. Bina Cipta, Jakarta.

Jacobstein, J. M., \& Meersky, R. M. (1977). Legal Reseach Illustrated.

Johnson, A. S. (1994). Sociological of Law (Sosiologi Hukum) yang diterjemahkan oleh: Rinaldi Simamora, PT. 
Rineka Cipta, Jakarta.

Johnson, D. P. (1986). Teori Sosiologi : Klasik dan Moderen. Gramedia, Jakarta.

Jurisprudence, E. B. (1974). The Philosophy and Method of the Law. Cambridge Mass, Harvard University Press.

Juwana, H. (2006). Penegakan Hukum dalam Kajian Law Development: Problem dan Fundamen bagi Solusi Di Indonesia, Varia Peradilan XII No 244 Maret.

Kadafi, B. et al. (2001). Advocat Indonesia Mencari Legitimasi : Studi Tentang Tanggung Jawab Profesi Hukum di Indonesia. Pusat Studi Hukum dan Kebijakan Indonesia, The Asian Foundation.

Kansil, C. S. T. (1989). Pengantar Ilmu Hukum dan Tata Hukum Indonesia. Balai Pustaka, Jakarta.

Kartohadiprodjo, S. (1977). Pengantar tata Hukum di Indonesia. Ghalia Indonesia, Jakarta.

Kelsen, H. (2006). Teori umum Tentang Hukum dan Negara. Nusa Media, Bandung.

Kelsen, H. (2007). Teori Hukum Murni, dasar-Dasar Ilmu Hukum Normatif, diterjemahkan raisul Mutaqien : Pure Theory of Law (Berkely, University California Press,1978, Nusa Media, Bandung.

Khudaifah, D. (2004). Teorisasi Hukum : Studi Tentang Perkembangan Pemikiran Hukum di Indonesia 1945-1990. Muhamadiyah University Press, Surakarta.

Khun, T. S. (2002). The Structure of Scientific Revolution. PT. Remadja Rosda Karya, Bandung.

Kitab Undang-Undang Hukum Acara Pidana (KUHAP), UU No 8 Tahun 1981 dan penjelasannya, CV. Titik Terang, Yakarta, 1995.

Kitab Undang-Undang Hukum Pidana, Pustaka Yustisia, Jogjakarta, 2007.

Krisnawati, D. (2006). Bunga Rampai Hukum Pidana Khusus. Pena Pundi Aksara, Jakarta.

Kristiana, Y. (2006). Independensi Kejaksaan Dalam Penyidikan Korupsi. PT. Citra Aditya Bakti, Bandung.

Kusnardi, M., \& Ibrahim, H. (1988). Pengantar Hukum Tata Negara Indonesia. Pusat Studi Hukum Tata Negara FH.UII, Jakarta.

Kusumaatmadja, M. (2002). Konsep-konsep Hukum Dalam Pembangunan. Alumni Bandung.

Kusumah, M. W. (2001). Tegaknya Supremasi Hukum: Terjebak Antara Memilih Hukum dan Demokrasi. Remaja Rosdakarya, Bandung.

Kusumohamidjojo, B. (2004). Filsafat Hukum: Problematika Ketertiban Yang Adil. PT.Grasindo, Jakarta.

Lee, O. L. (1980). Pengertian Management. Balai pembina Administrasi UGB, Jogjakarta.

Lexy, J. M. (2004). Metodologi Penelitian Kualitatif. PT>Remaja Rosdakarya, Bandung.

Loqman, L. (1990). Analisys Hukum dan Perundang-undangan Kejahatan Terhadap Keamanan Negara Di Indonesia. Rangkuman Disertasi.

Louis, C. F., \& Jaffe, L. (1969). English and American Judges as Law Makers. Clarendon Press, Oxpord.

Lubis, M. S. (1989). Serba-Serbi Politik dan Hukum. CV.Mandar Maju, Bandung.

Lubis, T. M. (1981). bantuan Hukum Struktural Redistribuís kekuasaan dan Partisipasi dari bawah. Prisma No 5.

Machmudin, D. D. (2000). Pengantar Ilmu Hukum : Sebuah Sketsa. Refika Aditama, Bandung.

Madinger, J. (2000). Confidential Informant: Law Enforcements Most Valuable Tool. CRC Press, London-Newyork, Washington DC.

Makalah disampaikan pada Karya Latihan Bantuan Hukum. Diselenggarakan YLBHI dan LBH Surabaya, September, 1985.

Manan, A. (2005). Aspek-Aspek Pengubah Hukum. Pranada Media, Jakarta.

Manan, B. (2004). Teori dan Politik Konstitusi. FH-UII Press, Jogjakarta.

Mas'ud, J. (1992). Al Ra'id Mu'jam Lughawiyun Ashriyun. Cet VII, Beirut Dar'alilm lil al Malayin.

Melani, Membenahi Lembaga Peradilan, Media Universitas Pasundan Al-Mizan No 114, Juli 2000.

Mertokusumo, S. (1993). Bab-Bab tentang Penemuan Hukum. PT. Citra Aditya Bakti,Bandung. 
Mertokusumo, S. (2001). Mengenal Hukum: Suatu Pengantar. PT. Radja Grafindo Persada, Jakarta.

Mertokusumo, S. (2002). Mengenal Hukum: Suatu Pengantar. Liberty, Jogjakarta.

Mertokusumo, S. (2004). Penemuan Hukum: Sebuah Pengantar. Liberty, Jogjakarta.

Mochamad Mahfud, M. D. (1997). Politik Hukum Untuk Indefendensi Lembaga Peradilan. Jornal Hukum, FH-UII, Jogjakarta, 4(9).

Moelyatno, Azas-azas Hukum Pidana, Rinema Cipta, Jakarta,1993.

Moelyatno. (1955). Perbuatan Pidana dan Pertanggungan Jawab dalam Hukum Pidana. Pidato Dies Natalis UGM, Jogjakarta.

Moelyatno. (1969). Perbuatan Pidana dan Pertanggungan Jawab Pidana Dalam Hukum Pidana. Seksi Kepidanaan, FH-UGM, Jogjakarta.

Molan, M., Bloy, D., \& Lanser, D. (2003). Modern Criminal Law (5th ed.). Convendish Publishing, Ltd, London.

Moten, A. R. (2011). Political Science : An Islamic Perspective. Pustaka, Bandung.

Muhamad, R. (1997). Urgensi Dan Upaya Revitalisasi Lembaga Peradilan. Jornal Hukum, FH-UII, 4(9).

Mukti Arto, A. (2001). Mencari Keadilan: Kritik dan Solusi Terhadap Praktik Peradilan Perdata di Indonesia. Pustaka Pelajar, jogjakarta.

Muladi. (Ed.). (2005). Hak Azasi manusia: Hakekat, Konsep dan Implikasinya Dalam Perspektif Hukum Dan Masyarakat. Refika Aditama, Bandung.

Nasution, A. B. (1998). Bantuan Hukum di Indonesia. LP3S, Jakarta.

Nisjar, K., \& Winardi. (1998). Teori System dan Pendekatan System dalam Bidang Manajemen. CV. Mandar Maju, Bandung.

Noer, D. (1965). Pengantar Ke Pemikiran Politik. Dwipa, Medan.

Nonet, P., \& Selznick, P. (2003). Law \& Society In Transition: Toward Responsive Law. In T. R. E. Bosco (Eds.), Hukum responsif: Pilihan Dimasa Transisi. Ford Fondation Huma, Jakarta.

Notohamidjojo, O. (1967). Makna Negara Hukum. Badan Penerbit Kristen, Jakarta.

Packer, H. L. (1968). The Limit of The Criminal Sanction. Stanford University Press, Stanford California.

Parsons, T. (1996). Societies, Evolutionary and Corporative Perspective. Englewood Cliffs, N.J. Prentice Hall.

Patra, J. W. L. (1978). Analizing The Criminal Justice System. Toronto : Lexington Books.

Peters, A. A. G., \& Siswosoebroto, K. (1998). Hukum dan Perkembangan Sosial (Buku Teks Sosiologi Hukum). Pustaka Sinar Harapan, Jakarta.

Piliang, Y. A. (2004). Post realitas: Realitas Kebudayaan dalam Era Pos Metafisika. Jalasutra, Jogjakarta.

Podgorecki, A., \& Whelan, C. J. (2000). Sociological Aproaches to Law, (Pendekatan Sosiologis Terhadap Hukum) yang diterjemahkan oleh Rnc Widyaningsih \& G Kartaspoetra, PT.Bina Aksara, Jakarta.

Poernomo, B. (1982). Asas-Asas Hukum Pidana. Ghalia Indonesia, Jakarta.

Poernomo, B. (1984). Orientasi Hukum Acara Pidana Indonesia. Amarta Buku, Jogjakarta.

Poerwadarminta. (1976). Kamus Umum Bahasa indonesia. Balai Pustaka, Jakarta.

Pollack, E. H. (1967). Fundamental of Legal Reseach. Brooklyn, The Fondation Press.

Pound, R. (1953). An Introduction to the Philosophy of Law. New Haven, Yale University Press.

Prodjodikoro, W. (1989). Asas-asas Hukum Pidana di Indonesia. Eresco, bandung.

Purbacaraka, P., \& Soekanto, S. (1979). Perundang-undangan \& Yurisprudensi. Alumni, Bandung.

Puspoprodjo, Heurmeunetik, Pustaka Setia, Bandung, 2004.

Putra, A. S. (2003). Teori Hukum Kritis : Struktur Ilmu Dan Riset Teks. PT. Citra Aditya Bakti, Bandung.

Putra, F., \& Arief, S. (2001). Kapitalisme Birokrasi. Puspek Averros, Lkis.

Rachbini, D. J. (2006). Ekonomi Politik. Ghalia Indonesia, Jakarta.

Radbrucht, G. (1961). Einfuhrung in die Rechtswissenschaft. Stuttgart: K.F. Koehler. 
Radhie, T. M. (1873). Pembaharuan Hukum dan Politik Hukum dalam Rangka Pembangunan Nasional. Jurnal Prisma, No 6 Tahun II desember.

Rahardjo, S. (1986). Hukum dan Masyarakat. Angkasa, Bandung.

Rahardjo, S. (1997). Pembangunan Hukum Nasional dan Perubahan Sosial. dalam Artidjo Alkotsar (ed) Identitas Hukum Nasional, FH-UII, Jogjakarta.

Rahardjo, S. (19979). Hukum dan Perubahan Sosial: Suatu Tinjauan Teoritis Serta Pengalaman-Pengalaman di Indonesia. Alumni, Bandung.

Rahardjo, S. (1998). Hukum dan Birokrasi, Makalah pada diskusi Panel Hukum dan Pembangunan dalam rangka Catur Windu, FH-Undip.

Rahardjo, S. (1998). Sistem Peradilan Pidana dalam wacana Control Social, jurnal Hukum Pidana dan Kriminologi. Vol 1 tahun 1998, Citra Aditya Bakti, Bandung.

Rahardjo, S. (1999). Polisi Indonesia Mandiri. Program Pasca Sarjana kajian Ilmu Kepolisian, UI, Jakarta, Kerjasama dengan Yayasan Obor Indonesia.

Rahardjo, S. (2000). Ilmu Hukum. PT.Citra Aditya Bakti, Bandung.

Rahardjo, S. (2000). Wajah Hukum di Era Reformasi: (Kumpulan Karya Ilmiah Menyambut 70 tahun Prof.DR.Satjipto Rahardjo), Citra Aditya bakti, bandung.

Rahardjo, S. (2003). Mempercepat Reformasi. Kompas.

Rahardjo, S. (2003). Mengana Undang-Undang terlalu Di Ributkan. Kompas.

Rahardjo, S. (2003). Sisi-sisi Lain dari Hukum Di Indonesia. Buku Kompas, jakarta.

Rahardjo, S. (2003). Supremasi Hukum yang Benar, Kompas.

Rahardjo, S. (2004). Ilmu Hukum: Pencarian, Pencerahan dan Pembebasan. Muhamadiyah University Press, Surakarta.

Rahardjo, S. (2004). Penegakan Hukum Kolektif. Kompas.

Rahardjo, S. (2004). Sosiologi Hukum: perkembangan Metode dan Pilihan Masalah. Muhamadiyah University Press, Surakarta.

Rahardjo, S. (2007). Masalah penegakan Hukum Progresif. Penerbit Buku Kompas, Jakarta.

Ranggawidjaya, R. (1998). Pengantar Ilmu Perundang-undangan Indonesia. CV Mandar Maju, Bandung.

Ranoemihardja, R. A. (1976). Hukum Acara Pidana. Tarsito, Bandung.

Rapar, J. H. (1988a). Filsafat Politik Plato. PT. Rajawali Press, Jakarta.

Rapar, J. H. (1988b). Filsafat Politik Aristoteles. PT.Rajawali Press, Jakarta.

Rasjidi, L., \& Wyasa Putra, L. B. (1998). Hukum Sebagai Suatu System. PT. Remaja Rosdakarya, Bandung.

Reksodipuro, M. (1993). Sistem peradilan Pidana Indonesia (melihat Kepada Kejahatan dan Penegakan Hukum dalam batas-batas Toleransi). Pidato Pengukuhan Guru Besar, FH-UI.

Riewanto, A. (2007). Ensiklopedi PEMILU, ELSAB. Pajar Pustaka, Jogjakarta.

Ritzer, G. (2004). Sosiologi Ilmu Pengetahuan Berparadigma Ganda (terjemahan). PT. Radja Grafindo Persada, Jakarta.

Robson, W. A. (1954). The University teching of Social Science: Political Science. Paris, Unesco.

Rukmini, M. (2003). Perlindungan HAM melalui Asas Praduga Tidak Bersalah dan Asas Persamaan Kedudukan Dalam Hukum Pada Sistem Peradilan Pidana Indonesia. Alumni, Bandung.

Sabuan, A. et al. (1994). Hukum Acara Pidana. Angkasa, Bandung.

Saleh, W. (1977). Kehakiman dan Peradilan. Ghalia Indonesia, Jakarta.

Salman, O., \& Susanto, A. F. (2004). Beberapa Aspek Sosiologi Hukum. Alumni, Bandung.

Samosir, D. (2002). Fungsi Pidana Penjara Dalam Sistem Pemidanaan di Indonesia. Putra Abardin.

Sardar, Z., \& Abrams, I. (2004). Mengenal Chaos For Begginers. Mizan, Bandung.

Saukani, I., \& Thohari, A. (2004). Dasar-Dasar Politik Hukum. Radja Graffindo Persada, Jakarta. 
Schaper, S. (1973). The Political Criminal. The Free Press, New York.

Schiff, D. N. (1987). Hukum Sebagai Suatu Fenomena Sosial. In D. A. Podgorecki, \& C. J. Whelan (Eds.), Sociological Approaches To Law. yang diterjemahkan oleh Rnc. Widyaningsih \& G. Kartasapoetra, PT. Bina Aksara, Jakarta.

Schuyt, D. T., \& Lubis, M. (1986). Bantuan Hukum dan Kemiskinan Struktural. LP3ES, Jakarta.

Seres, K. J. C., Schinkel, M. P., \& Vogelaar, F. O. W. (Eds.). (2003). Criminalization of Competition Law Enforcement : Economic and Legal Implication for the UE Member State. Oxpord University Press.

Sidharta, B. A. (2000). Refleksi Tentang Struktur Ilmu Hukum: Sebuah Penelitian tentang Fundasi Kefilsafatan dan Sifat Keilmuan Ilmu Hukum Sebagai Landasan Pengembangan Ilmu Hukum Nasional. Mandar Maju, Bandung.

Sidharta, B. A. (2001). Disiplin Hukum : Tentang Hubungan Antara Ilmu Hukum, Teori Hukum dan Filsafat Hukum. Ulang Tahun FORDISKUM, Bandung.

Simon, J. (2007). Governing Trought Crime. Oxpord University Press, New York.

Sinaga, P., \& White, B. (1979). Beberapa aspek kelembagaan di Pedesaan jawa dalam Hubungannya dengan Kemiskinan Struktural. Seminar HIPIIS, Malang.

Slobogin, C. (2007). Proving The Un Provable The Role of Law, Science and Speculation in Adjudicating Culpadility andDangerousness. Oxpord University Press.

Soedarto. (1981). Hukum dan Hukum Pidana. Alumni, Bandung.

Soedarto. (1983). Hukum Pidana dan Perkembangan Masyarakat. Sinar Baru, Bandung.

Soekanto, S. (1967). Penegakan Hukum dan Kesadaran Hukum. Makalah Seminar Hukum Nasional Ke IV, Jakarta.

Soekanto, S. (1978). Penegakan Hukum Lalu Lintas Dan Kepatuhan Hukum Terhadapnya, Majalah Hukum \& Pembangunan No 1 januari 1978, FH-UI, Jakarta.

Soekanto, S. (1983). Bantuan Hukum : Suatu Tinjauan Sosio Yuridis. Ghalia Indonesia, Jakarta.

Soekanto, S. (1983). Faktor-faktor yang Mmempengaruhi Penegakan Hukum. Radjawali Press, Jakarta.

Soekanto, S. (2001). Sosiologi Suatu Pengantar. PT Radja Grafindo Persada, Jakarta.

Soekanto, S., \& Mamudji, S. (1985). Penelitian Hukum Normatif. CV. Radjawali, Jakarta.

Soesilo, R. (1974). Pokok-Pokok Hukum Pidana: Peraturan Umum dan Delik-delik Khusus. pelita, Bogor.

Souryal, S. S. (1990). Ethic in Criminal Justice. Cipta Manunggal, Jakarta.

Spinellis, D. (1994). Crime of Politicians in office, dalam Helmut EEP, (ed), Crime bay Goverment, Bahan XV th International Congress of Penal Law : Rio de Jeneiro,4-10 September 1994.

Sri Sumantri, M. (1993). tentang Lembaga Negara Menurut UUD 1945. PT.Citra Aditya Bakti, Bandung.

Stone, J. (1966). Program and Moment in The Borderlands of Law and Social Science. Dalam Law In Social Science. The Second Half Century, Minneapolis : University of Minneasota.

Subayak, R. F. S. (1985). Beberapa Pemikiran Kearah Pemantapan Penegakan Hukum. INDH-HILL, Co, Jakarta.

Subroto, A. W., \& Widiartana, G. (2005). Pembaharuan Hukum Acara Pidana. Citra Aditya Bakti, Bandung.

Sumarno, A. P., \& Lukiswara, Y. (1992). Pengantar Studi Ilmu Politik. PT.Citra Aditya Bakti, Bandung.

Sumaryono, A. (2002). Etika \& Hukum : Relevansi Teori Hukum Kodrat Aquinas. Pustaka Filsafat, Kanisius, Jogjakarta.

Sunaryo, S. (2005). Kapita Selekta Sistem Peradilan Pidana. UMM Press, Malang.

Sunggono, B., \& Harianto, A. (2001). Acuan Hukum dan Hak asasi Manusia. Mandar Maju, Bandung.

Suparno, P. (1997). Filsafat Konstruktivisme Dalam Pendidikan, Pustaka Filsafat. Kanisius, Jogjakarta.

Suringa, H., \& Terpetik dalam P.A.F. Lamintang. (1997). Dasar-Dasar Hukum Pidana Indonesia. PT. Citra Aditya Bakti, Bandung.

Susanto, A. F. (2007). Hukum Dari Consilience Menuju Paradigma Hukum Konstruktif-Transgresif. PT,. Refika 
Aditama, Bandung.

Susanto, I. S. (1992). Pemahaman Kritis Terhadap Reaksi Sosial. Majalah Hukum, No 9 Tahun.

Susanto, I. S. (1992). Pendekatan Kritis terhadap realitas Sosial, Tulisan Dalam Lokakarya Nasional untuk Pengembangan sumber Daya IMKA, Karang pandan.

Suseno, F. M. (2003). Etika Politik: Prinsip-prinsip Moral Dasar Kenegaraan Moderen. PT. Gramedia Pustaka Utama, Jakarta.

Sutiyoso, B., \& Puspitasari, S. H. (2005). Aspek-aspek Perkembangan Kekuasaan Kehakiman Di Indonesia. UII Press, Jogjakarta.

Syarbini, S. (2004). Sosiologi dan Politik. Ghalia Indonesia, Jakarta.

Syirazi, I. M. (2004). Islam Melindungi Hak-Hak Tahanan. Pustaka Zahra, Jakarta.

Thalhah, H. M. (2003). Dinamika Ketatanegaraan Indonesia di Era Reformasi. FH. Unigoro, Bojonegoro.

Thobaben, R. G. (1995). Issues In American Political Life. Prentice Hall.

Undang Undang No 10 Tahun 2008 Tentang Pemilihan Umum, DPR, DPD dan DPRD.

Undang-Undang No 1 Tahun 1979 tentang Ekstradisi.

Undang-Undang No 16 Tahun 2004 Tentang Kejaksaan.

Undang-Undang No 18 tahun 2003 Tentang Advocat.

Undang-Undang No 2 Tahun 2002 tentang Kepolisian.

Undang-Undang No 22 tahun 2002 tentang Grasi.

Undang-Undang No 27 tahun 1999 tentang perubahan KUHP Yang Berkaitan Dengan Kejahatan Terhadap Keamanan Negara.

Undang-Undang No 31 Tahun 1999 tentang Pemberantasan Tindak Pidana Korupsi.

Undang-Undang No 4 Tahun 2004 Tentang Kekuasaan Kehakiman.

Undang-Undang No 5 Tahun 2004 Tentang Mahkamah Agung.

Undang-undang No 8 Tahun 2004 Tentang Peradilan Umum.

Utomo, W. H. (2005). Hukum Kepolisian di Indonesia. Prestasi Pustaka, Jakarta.

Wagiman, W. (2005). Contempt of Court dalam rancangan KUHP. ELSAM, Jakarta.

Wahid, A., \& Labib, M. (2005). Kejahatan Mayantara. Refika Aditama, Bandung.

Wahyono, P. (1986). Indonesia Berdasarkan Atas Hukum. Ghalia Indonesia, Jakarta.

Warasih, E. (2005). Pranata Hukum : Sebuah Telaah Sosiologis. PT. Suryandaru Utama, Semarang.

Wehr, H. (1980). A Dictionary of Modern Written Arabic. London :Mac Donald and Avans Ltd.

Wignyosoebroto, S. (1999). Masalah Metodologik Dalam Penelitian Hukum sehubungan dengan Masalah Keragaman Konseptualnya. Pelatihan Metodologi Ilmu Soosial, Semarang.

Wignyosoebroto, S. (2002). Hukum: Paradigma, Metode dan Pilihan Masalahnya. ELSAM_HUMA, Jakarta.

Wilardjo, L. (1998). Asas-asas Kekeluargaan. Suara Pembaharuan.

Wilson, W. (2002). Central Issues In Criminal Theory. Oxpord-Portland Oregon.

Wiradipradja, E. S. (2001). Law Persfektife of Good Governance in Indonesia. Syiar Madani (Jurnal Ilmu Hukum) Vol VIII No 3 tahun 2001.

Wojowasito. (1997). Kamus Umum bahasa Belanda-Indonesia. Ikhtiar Baru, Jakarta.

Wolfgang Friedman. (1953). Legal Theory. Steven \& Song Ltd London.

Wrong, D. (Ed.). (2003). Max Weber: Sebuah Khazanah. Ikon Tiralitera, Jogjakarta.

Yusriadi. (2000). Alternatif pemikiran tentang Paradigma Ilmu Hukum dala Wajah Hukum di Era Reformasi (Kumpulan Karya Ilmiah Menyambut 70 Tahun Prof.DR.Satjipto Rahardjo). Citra Aditya Bakti, Bandung.

Zara, M. Y. (2005). Kematian Misterius Para Pembaharu Indonesia. Pinus Book Publisher, Jogjakarta.

Zarkasy, H. F. (2008). Radikalisme VS Liberalisme. Gatra, 02 Th XV, 20-26. 
Zohar, D., \& Marshaal, I. (2001). SQ : Spiritual Intellegence-The Ultimate Intellegence, (Terjemahan) : SQ : Memanfaatkan Kecerdasan Spritual Dalam Berfikir Integralistik dan Holistik untuk memaknai kehidupan. Mizan, Bandung.

\section{Copyrights}

Copyright for this article is retained by the author(s), with first publication rights granted to the journal.

This is an open-access article distributed under the terms and conditions of the Creative Commons Attribution license (http://creativecommons.org/licenses/by/4.0/). 